\title{
A integração do imigrante no Brasil em uma perspectiva comparada com Canadá: o caso dos haitianos ${ }^{1}$
}

\section{The integration of the immigrant in Brazil in a comparative perspective with Canada: the case of the Haitians}

\author{
Isaías Albertin de Moraes ${ }^{2}$ \\ Mônica Heinzelmann Portella de Aguiar ${ }^{3}$
}

Submetido em 14 de dezembro de 2017 e aprovado em 17 de janeiro de 2018.

\begin{abstract}
Resumo: A pesquisa, a partir dos desafios que a recente imigração de haitianos impôs ao Brasil, buscou investigar a atual política pública de integração do imigrante no país em uma perspectiva comparada com o Canadá. O estudo tem como método de análise a Política Comparada e como objetivo de metodologia a pesquisa exploratória. $\mathrm{O}$ artigo é dividido em duas seções, a primeira apresenta a política de imigração brasileira e a segunda a canadense, sendo feitas comparações entre ambas na segunda parte e nas considerações finais.
\end{abstract}

Palavras-chaves: Política de Integração do Imigrante. Política Comparada Brasil e Canadá. Haitianos.

Abstract: The article, due to the challenges brought by the recent immigration of Haitians to Brazil, seeks to investigate and compare the current Brazilian immigrant integration policy to the Canadian one. A Comparative Policy analysis method has been used to achieve the aims of an exploratory research. The article is divided in two parts, first a presentation of the Brazilian immigration policy and then the Canadian one. The comparison between both occurs in the second part, as well as in the final considerations.

Keywords: Immigrant Integration Policy. Brazil and Canada Comparative Politics. Haitians.

Segundo relatório Global trends: forced displacement do Alto Comissariado das Nações Unidas para Refugiados (ACNUR), ao final de 2015, foram deslocadas de modo forçado mais de 60 milhões de pessoas. Elas tiveram de deixar suas casas em razão de perseguição e de violência generalizada. O Brasil, apesar de ter sido historicamente construído social e politicamente com a vinda de vários imigrantes durante décadas (italianos, portugueses, poloneses, ucranianos, alemães, 
japoneses), enfrentou uma significativa repulsão de brasileiros para diferentes países principalmente por motivos econômicos nos meados do século XX.

No início do século XXI, todavia, o perfil do país está se modificando novamente, além da repatriação de diversos brasileiros, que deixaram o país nas décadas passadas, está havendo a atração de novos imigrantes. Segundo Sistema Nacional de Cadastramento de Registro de Estrangeiros (SINCRE) de 2010 a 2015 o número de imigrantes que entrou no país aumentou em 160\%; e de acordo com Observatório das Migrações Internacionais (OBMigra), os trabalhadores imigrantes no Brasil cresceu 131\% no mesmo período.

Desde 2010, o país se transformou em novo destino para imigrantes, entre esses destacam: peruanos, chineses, bolivianos, venezuelanos, angolanos, ganeses, senegaleses, bengaleses , sírios e haitianos. A emigração brasileira continua, mas apresenta outro perfil, trata-se da chamada fuga de capital humano, a saída de profissionais mais especializados. O Brasil entrou definitivamente nas novas transformações e na complexidade da imigração internacional. O maior fluxo de imigrantes para o país, como é o caso dos haitianos, entretanto, expôs a fragilidade e a desorganização das instituições nacionais para lidar com situações que envolvam imigração. Periodicamente, os meios de comunicação denunciam os descasos e os maus tratos que os imigrantes estão sujeitos.

Figura 1

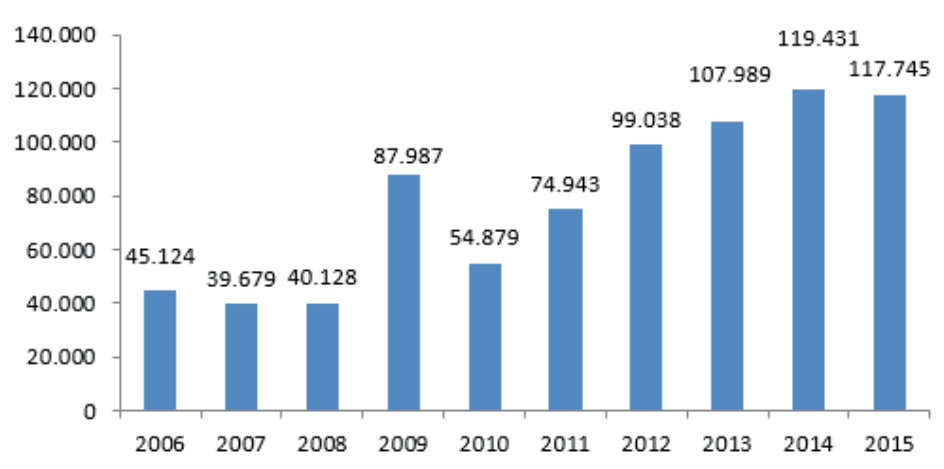

Fonte: (SINCRE) da Polícia Federal 
Diante desse quadro, a pesquisa objetivou comparar a política de integração do imigrante no Brasil e no Canadá, usando como estudo de caso a imigração haitiana. A escolha do caso foi em virtude de que a imigração haitiana para o Brasil pode ser comparada historicamente, segundo declaração do Ministério das Relações Exteriores (MRE) ao jornal Folha de São Paulo, à de italianos e de japoneses desembarcados entre o período imperial e os primeiros anos da República, respeitando as proporções.

A seleção da unidade de análise comparativa com o Brasil, isto é, o Canadá, observou dois critérios metodológicos. São eles: a) utilizar a comparação entre unidades políticas com longa tradição migratória de haitianos e outros povos, especialmente no que diz respeito aos modernos fluxos migratórios do século XX e XXI, e b) possuir políticas regulatórias e integracionistas dos imigrantes reconhecidas internacionalmente.

No caso especifico dos imigrantes haitianos, os países que mais os receberam, nas últimas décadas, além do Brasil foram: Estados Unidos da América (EUA); República Dominicana, França e Canadá. Para o primeiro quesito de escolha das unidades de análises, os autores apoiaram-se nos dados do Migration Policy Institute $\mathrm{e}^{4}$ em conhecimentos históricos e sociológicos prévios. A pesquisa identificou três países que correspondiam ao critério estipulado: EUA, República Dominicana e Canadá.

Em relação ao segundo item, a pesquisa baseou-se nos índices Migrant Integration Policy Index - MIPEX $X^{5}$ e Protection Indicators da ACNUR. De posse desses dados, o estudo averiguou que o Canadá, entre os países elencados, e segundo as análises dos índices citados, foi que melhor atendeu os dois critérios de escolhas das unidades analíticas. Primeiro, o país da América do Norte foi formado significativamente por imigrantes, entre eles: russos, gregos, chineses, franceses, ingleses, italianos, portugueses, haitianos, etc. Além disso, o Canadá é reconhecido internacionalmente pela sua regulação e política de integração de imigrantes e refugiados, sendo citado como modelo pelo $A C N U R$ e constando entre os seis melhores para receber imigrantes, segundo o MIPEX (MIPEX; ACNUR, 2017).

A comparação na ciência política, segundo Schmitter (2001, p.161), além de ser um campo de conhecimento, quando estuda os outros países e outros povos, é um importante método de análise. A presente pesquisa, portanto, procurou utilizá-la de forma 
analítica, visando examinar as similitudes e as diferenças entre unidades políticas. Os resultados foram correlacionados com as teorias de políticas migratórias.

A descrição da abordagem metodológica da pesquisa levou em consideração que a política comparada deve procurar incluir aspectos ligados às oportunidades e à aleatoriedade de cada caso. Com isso, é necessário o exame cuidadoso de cada unidade, com descrições espessas e entendimento interpretativo, contextualizando as descobertas da pesquisa e considerando os contrastes, pois os padrões variam de acordo com o contexto e com a história (RAGIN, 2014, p 20).

A metodologia da política comparada deve enfatizar a lógica tripartite, integrando regularidades estatísticas com testes de teoria, e examinando os casos a partir de um viés narrativo, observando a importância da história (LAITIN, 2002, p. 2-3). É de vital importância, nesse sentido, o exame do contexto do caso, construindo uma narrativa cronológica e histórica, estabelecendo os valores de variáveis dependentes e independentes (GEORGE \& BENNETT, 2005, p.157). Tendo em mente, dessa maneira, a importância da história, do contexto social, nacional e internacional, bem como dos atores envolvidos nas construções de políticas públicas, o artigo enfatizou a narrativa histórica em grande parte.

Apesar dessa abordagem histórica, o texto não é meramente descritivo. O objetivo da metodologia adotada foi o exploratório, ou seja, a pesquisa visou proporcionar maior familiaridade com o problema, explicitá-lo e realizar análises críticas ao conteúdo durante a narrativa. A exposição lógico-argumentativa foi apresentada em duas seções, a primeira se dedica a expor a política de imigração brasileira, a segunda a canadense, comparando-a com a do Brasil durante a explanação e nas considerações finais.

Os procedimentos técnicos priorizados foram: bibliográficos, documentais e entrevistas semiestruturadas. Em um primeiro momento efetuou-se o levantamento, a seleção, o fichamento e o arquivamento de informações relacionadas ao estudo. Adotouse uma abordagem sistemática por meio da avaliação crítica dos dados bibliográficos e documentais, mormente de fontes primárias estatais, internacionais e de ONGs, como: legislações, decretos, discursos, tratados e relatórios, além das secundárias, por exemplo: livros, revistas, jornais, documentários e filmes. Em uma segunda fase realizaram-se entrevistas com haitianos presentes na cidade de São Paulo. 


\section{A política de integração do imigrante no Brasil}

Entre o fim da escravidão e a década de 1920, o Brasil tornou-se receptor de mãode-obra estrangeira, recebendo grande fluxo de população majoritariamente oriunda da Europa. Foram implementadas políticas assertivas para atrair o trabalhador estrangeiro ao Brasil, tais como a subvenção das despesas de passagem dos imigrantes. A entrada constante de mão-de-obra mantinha os salários baixos e promovia o branqueamento da população, desejo da elite brasileira (LESSER, 1994, p. 85-86).

O quadro favorável à imigração foi alterado pela crise econômica de 1929 e a revolução que levou Getúlio Vargas ao poder em 1930. A Constituição de 1934, "tendo em vista a proteção social do trabalhador e os interesses econômicos do País" estabeleceu a Lei de Cotas que restringiu fortemente a entrada de estrangeiros (Art. 121, $\S 6^{\circ}, \S 7^{\circ}$ ) e que se manteve na Constituição do Estado Novo (1937). A intenção era a regularização dos fluxos nacionais.

Com o fim da Segunda Guerra Mundial, reviu-se, no cenário internacional e no Brasil, o termo de refugiado político, alargando-o aos casos de emigração forçada. Nesse período, verificou-se maior abertura brasileira para receber imigrantes de diversas nacionalidades. Essa admissão dependeu, contudo da atratividade do estrangeiro para o país e estima-se que até 1951 o número não tenha ultrapassado as 25.000 pessoas (PAIVA, 2009, p. S/N).

Tal política perdeu espaço após o Golpe Civil-Militar de 1964. Pautada pela doutrina da segurança nacional, a ditadura olhava com desconfiança o estrangeiro, vendo nele uma possível ameaça à ordem pública. Em 1980, foi criado o Conselho Nacional de Imigração e elaborado o Estatuto do Estrangeiro que limitava os direitos políticos e civis dos imigrantes em uma clara evidência da natureza repressora da legislação nacional (OLIVEIRA, 2017, p. 171-172).

Em 1985, a redemocratização pouco alterou as restrições da política brasileira de imigração. O Estatuto do Estrangeiro, instituído em 1980 e sob a ótica da Lei de Segurança Nacional, continuou a prevalecer. Foi sob essa lei que, em 2010, iniciou-se um dos mais recentes fluxos migratórios para o Brasil, o dos haitianos.

Em 2011, o grande terremoto que atingiu o Haiti intensificou o movimento migratório de haitianos em direção ao Brasil. A princípio, os haitianos solicitaram refúgio 
com base no Direito Internacional dos Refugiados e na legislação brasileira. O Conselho Nacional para os Refugiados (Conare), no entanto, entendeu que o motivo apresentado por eles (desastre natural, crise socioeconômica) não se enquadrava nas hipóteses de perseguição elencadas pelo direito internacional e pela lei brasileira vigente. O Conare, dessa maneira, remeteu o caso ao Conselho Nacional de imigração (CNIg) com vistas a obter uma solução legal para a questão. Em decisão histórica, o CNIg concedeu visto humanitário de residência aos haitianos, possibilitando que eles trabalhem e estudem no Brasil. Além dessas medidas, o Conare aprovou um protocolo permitindo a obtenção do Cadastro de Pessoa Física e da Carteira de Trabalho e Previdência Social (MORAES, ANDRADE. MATTOS, 2012, p.103-104).

Desde 2014, os haitianos lideram o ranking de entrada de estrangeiros no país. A Polícia Federal estima em mais 78.000 o total de haitianos residindo em território nacional. Muitos desses haitianos entram com pedido de refúgio. Apesar dos haitianos não se encaixarem plenamente no conceito vigente de refugiado, que pela Lei 9474 (Art.1), reconhece como tal aqueles que podem vir a sofrer perseguição "por motivos de raça, religião, nacionalidade, grupo social ou opiniões políticas" ou cujo país passa por "grave e generalizada violação de direitos humanos". A Lei faculta ao estrangeiro que chega ao Brasil "solicitar reconhecimento como refugiado a qualquer autoridade migratória que se encontre na fronteira" a qual deve lhe proporcionar "as informações necessárias quanto ao procedimento cabível" (Art.7). Uma interpretação mais humanitária da Lei permite que os haitianos tenham a opção de requerer um visto solicitando residência permanente. Até 2012, só podiam ser concedidos 1.200 vistos humanitários anuais, mas subsequentemente o CNIg eliminou esse limite.

Tabela 1. Número de haitianos que imigraram para o Brasil (2011 -2016)

\begin{tabular}{|c|c|c|c|c|c|}
\hline 2011 & $\mathbf{2 0 1 2}$ & $\mathbf{2 0 1 3}$ & $\mathbf{2 0 1 4}$ & $\mathbf{2 0 1 5}$ & $\mathbf{2 0 1 6}$ \\
\hline 481 & 4.282 & 5.610 & 10.692 & 14.535 & 42.465 \\
\hline
\end{tabular}

Fonte: (SINCRE) da Polícia Federal. 
Em 2017, em virtude da complexidade que se tornou a questão dos imigrantes no país e em razão do arcaísmo do Estatuto do Estrangeiro, foi sancionada a Lei n ${ }^{0} 13.445$. A nova Lei da Migração brasileira procura dar maior ênfase aos direitos humanos e ao combate à xenofobia. Ela trouxe diversos avanços legislativos para o Brasil como: a acolhida humanitária, o reconhecimento da apátrida, a tipificação do crime de contrabando de pessoas e se estende aos brasileiros no exterior (OLIVEIRA, 2017, p.175). Contudo, ela ainda mantém a competência privativa da União de legislar sobre a temática, além de administrativamente ser pouco inovadora ao não criar, por exemplo, uma Agência Nacional de Imigração. A Polícia Federal continua a ser a principal fiscalizadora das fronteiras e da atividade migratória brasileira.

Entrevistas realizadas com haitianos permitiram validar algumas hipóteses para a escolha do Brasil como novo centro de migração. Entre elas destacam-se: a imposição de um gargalo no acesso a tradicionais destinos de migração como EUA e Europa; a maior presença do Brasil no Haiti graças à liderança, de 2004 a 2017, da Missão das Nações Unidas para a Estabilização do Haiti (Minustah); a imagem cultural do país (o jogo da seleção brasileira de futebol no país em 2004, inclusive foi citado), a prosperidade transmitida pela economia brasileira em 2010 e a adoção do visto humanitário.

Nota-se que na imigração haitiana, para o Brasil, há uma complexidade multifatorial. Evidenciam-se fatores internos e elementos materiais e intersubjetivos tanto do país de origem quanto do receptor, além, de cenários socioeconômicos e políticos externos que impactaram a dinâmica imigratória internacional haitiana. A despeito da multifatoriedade analítica nos fenômenos de migração internacional, o processo é influenciado, segundo Zolberg (2006, p.11), mormente, pela política.

[...] é um processo essencialmente político, pois as políticas relevantes abrangem não só a regulação do movimento através das fronteiras do Estado, mas também as regras que dispõem sobre a aquisição, manutenção, perda ou renúncia voluntária da cidadania em todos os seus aspectos - político, social, econômico e cultural (ZOLBERG, 2006, p. 11).

As ondas migratórias como a haitiana, dessa maneira, respondem às ações que abrangem não só a regulação do fluxo através das fronteiras do Estado, mas também às 
regras que dispõem sobre a aquisição, a manutenção, a perda ou a renúncia voluntária da cidadania em todos os seus aspectos — político, social, econômico e cultural em determinados territórios. O autor afirma, desse modo, que a política migratória deve ser entendida como um aglomerado de ações governamentais com o intuito de regulamentar a entrada, a saída, a integração e a permanência de estrangeiros em seu território nacional (ZOLBERG, 2006, p.456).

Para Meyers (2004, p.199-200), as políticas migratórias podem ser categorizadas em duas subdivisões: 1) política de regulação ou controle imigratório: abrange regras e procedimentos que regulam a seleção e admissão de estrangeiros; 2) política de integração para imigrantes e refugiados: trata das condições dadas aos imigrantes residentes (condições de trabalho, moradia, educação e assistência social).

No Brasil, a primeira é de responsabilidade, segundo a Constituição da República Federativa do Brasil de 1988, única do governo federal. As políticas de integração, por outro lado, são orientadas por instituições e órgãos federais, mas as demais unidades federativas e a sociedade civil organizada possuem certa liberdade de financiamento, de planejamento administrativo e de execução.

A cultura integracionista apresentada ao imigrante e ao refugiado por parte do estado brasileiro, principalmente nas esferas estaduais e municipais da administração pública, é parca e difusa. Ao se dedicar ao tema, tornou-se cada vez mais evidente que um número significativo de imigrantes está vivendo em médias e pequenas cidades. A consciência de que a integração de migrantes ocorre em nível local, entretanto, no Brasil, ainda não entrou definitivamente nos discursos políticos e científicos sobre a integração. A ausência estatal, na recepção, no ordenamento e na integração dos fluxos migratórios internacionais no Brasil, faz com que ONGs e associações de imigrantes desempenham valorosos trabalhos de acolhida e de integração dos recém-ingressos no país.

O Brasil carece de uma Agência Nacional de Imigração, órgão que poderia centralizar as ações de regulamentação e orientar os municípios na integração dos imigrantes. A complexidade burocrática faz com que ao chegar, o imigrante seja registrado pela Policia Federal, sua identidade de estrangeiro obtida no Ministério da Justiça e sua carteira laboral no Ministério do Trabalho. A complexidade burocrática deixa o imigrante dependente da 
ajuda da sociedade civil organizada para compreender todo esse processo, bem como para se inserir na vida social, no mercado de trabalho e para utilizar serviços públicos.

Importantes ONGs, como Cáritas, Conectas, Viva Rio, Centro Zanmi, Adus, I Know My Rights Brasil, etc. desempenham a função de acolher, de orientar e de amparar os imigrantes. No caso dos haitianos, seu histórico recente de imigração os privou da criação de redes próprias de acolhida, como as existentes em processos migratórios mais antigos, como de italianos e de libaneses. A função de acolhida fica quase que exclusivamente com a sociedade civil organizada. Entretanto, a amplitude de atuação dessas ONGs é limitada, concentrando, sobretudo, nos grandes centros urbanos, trabalhando, não raramente com voluntariados e possuindo recursos orçamentários restritos.

Muitos dos imigrantes haitianos que vieram para o Brasil estão domiciliados em pequenas e médias cidades do sul, do norte e do centro-oeste. Essas não contam com Casas de apoios para acolhida dos imigrantes que ficam sujeitos a preconceitos, a exploração de todos os tipos, inclusive laboral, e sem seus direitos de acesso aos serviços públicos. A título de exemplo, a cidade de São Paulo, com longa tradição em receber imigrantes, somente em 2014, criou o seu Centro de Referência e Acolhida para Imigrantes. O modelo vem sendo copiado por outras cidades, como Porto Alegre e Florianópolis (OBMIGRA, 2017; FERNANDES, CASTRO, 2014, p.42).

Segundo Torpey (2000, p.46), a propagação das normas de direitos humanos, nas décadas recentes fez com que determinadas nações aceitassem fluxos aparentemente descontrolados de imigrantes ilegais. Essa desorganização na inserção do estrangeiro na sociedade local colocou, não raramente, o imigrante em situação de fragilidade e em condições indignas de humanidade. Ocorrências de desrespeito aos direitos humanos e falta de cidadania, como as recentes denúncias em relação à imigração haitiana para o Brasil enquadrar-se-iam nesse contexto. A ONG Conectas chegou a denunciar à Comissão Interamericana de Direitos Humanos da Organização dos Estados Americanos (CIDH/OEA) o tratamento desumano recebido pelos imigrantes haitianos no Acre (CONECTAS, 2013).

Infere-se que o Brasil, sob a égide dos princípios de direitos humanos, vem recebendo um significativo fluxo de imigrantes e de refugiados, sendo que a nacionalidade 
com maior número de representantes, nessa nova fase da imigração para o Brasil, ainda é a haitiana, no entanto a política de imigração brasileira exige passar por modernizações. Os municípios e as ONGs, com o auxilio da União, precisam estar preparados para auxiliar os recém-chegados, dando suporte jurídico, social, psicológico, cursos, oficinas, viabilizando, assim, sua integração social e cidadã, além da inserção na cadeia produtiva.

\section{A política de integração do imigrante no Canadá}

O Canadá é um país conhecido por ter sido povoado por imigrantes, embora essa política tenha sido inicialmente bastante restritiva. Em princípios dos anos 1930, a população canadense era de pouco mais de 10 milhões de pessoas, com quase metade dela resultando da entrada de imigrantes das três décadas anteriores. O perfil desse afluxo era predominantemente europeu sendo que grande parte da população total era constituída de britânicos $(51,9 \%)$ e franceses $(28,2 \%)(\mathrm{MCH})$. O país, na questão de imigração, estabelecia uma divisão entre países preferenciais e não preferenciais, favorencendo, dessa maneira, a entrada de europeus do norte com perfil para o trabalho rural como alemães, holandeses, poloneses e escandinavos. A política de seleção era dura e restringia a entrada de asiáticos, cobrando taxas elevadas de chineses e de indianos, estabelecendo uma quota para japoneses e isentando as nacionalidades europeias. A imigração negra era proibida por tratar-se de uma "raça pouco adaptada ao clima e às exigências do Canadá" (Decreto 1324 de 1911) ${ }^{6}$. Desta forma, em 1931, apenas 2,3 \% da população era composta por asiáticos e por descendentes dos nativos locais, os inuits. (CCR, 2000).

A Grande Depressão de 1929 e a eclosão da Segunda Guerra Mundial dificultaram o movimento migratório internacional e também impactaram o Canadá. Se entre 1926-30 ingressaram cerca de 720.000 pessoas, esse número se viu reduzido a 10\% entre 193640 e mais ainda durante a guerra. Entre 1940-45 apenas 60.900 pessoas conseguiram entrar no país. Nesse período, aumentaram as deportações e as exigências para obter a naturalização $(\mathrm{MCH})$. Os critérios eram aplicados com base em motivos políticos ideológicos (medo do comunismo) e étnicos raciais. Esse sistema de seleção vigorou para a aceitação dos refugiados no pós-guerra (CCR, 2000). 
Em 1950, foi criado o Ministério da Cidadania e Imigração. A política aplicada continuou sendo a de reserva geográfica, contemplando algumas categorias de europeus, excluindo negros e concedendo grande poder discricionário às autoridades migratórias (CCR, 2000). Foram abertas algumas exceções para a acolhida de refugiados. Em 1957, o Canadá recebeu mais de 37.000 húngaros fugindo da intervenção soviética e no Ano dos Refugiados (1959/60), o país aceitou 352 tuberculosos e suas famílias, suspendendo temporariamente suas exigências sanitárias.

O ponto de inflexão na política migratória do Canadá aconteceu em 1962, quando o Ministério da Cidadania e Imigração distendeu suas leis, sobretudo as que diziam respeito às reservas raciais, e aboliu a distinção entre nações preferenciais e não preferenciais. $\mathrm{O}$ Canadá, a partir desse momento, começou a estruturar uma rede governamental destinada especificamente a imigrantes, estabelecendo normativas e órgãos públicos, demonstrando, assim, o reconhecimento do Estado da necessidade da presença de grupos específicos de imigrantes no país.

Em 1967, inspirado no modelo australiano, foi estabelecido um sistema de pontuação, em vigor até hoje, e que avalia a elegibilidade do candidato à migração. Atributos como escolaridade, competências linguísticas e profissionais, saúde, renda são quantificados numa escala que chega aos 100 pontos. A metodologia é bastante complexa e foi remodelada em algumas ocasiões, mas tem a vantagem de proporcionar maior transparência às decisões, orientar o fluxo de entrada de acordo com as necessidades econômicas e demográficas do país e poder ser objeto de apelo em várias instâncias. Em 1969, o país assinou a Convenção relativa ao Estatuto dos Refugiados (1951) e seu Protocolo adicional (1967). A adoção dessas novas políticas permitiu um aumento na migração vinda do Caribe e da Ásia (GREEN \& GREEN, 1996, p.18).

Em 1971, o governo do Primeiro Ministro Joseph Trudeau implementou uma política de incentivo ao multiculturalismo. A ideia era transformar a diversidade cultural canadense em um símbolo nacional, logo a política começou a pregar a tolerância, a igualdade de direitos, o respeito às liberdades e a inclusão de diferentes etnias na vida política e social do país. O governo buscava, portanto, não somente receber os imigrantes e os refugiados, mas integrá-los na sociedade canadense (HELLY, 2002, p.07-08). 
Durante as décadas seguintes, o Canadá recebeu várias levas de perseguidos dos seus países de origem. Desde asiáticos, mormente chineses, fugindo da Revolução Cultural, ugandenses expulsos pelo regime de Idi Amin Dada, passando por chilenos perseguidos pela ditadura de Pinochet e libaneses escapando da guerra civil, até refugiados do Vietnã, do Laos e do Camboja, países em convulsões revolucionárias e guerras, além de poloneses quando do fechamento do sindicato Solidariedade (CCR, 2000).

O processo de migração haitiana para o Canadá iniciou-se durante a ditadura de François Duvalier (1957 - 1971). A escolha pelo país justificava-se pela identidade linguística - até hoje $90 \%$ dos haitianos presentes em território canadense vivem na província francesa do Quebec - e pelo fim das reservas raciais nas leis migratórias. Em 1966, o Ministério da Imigração registrou 84 imigrantes haitianos. A primeira leva de haitianos beneficiou-se da chamada "operação meu país" por meio da qual se entrava como estudante ou turista para depois regularizar a situação. Calcula-se que até 1976 tenham entrado 10.845 haitianos nessas condições. Esse primeiro fluxo migratório destacou-se pelo seu nível de instrução. Tratava-se de profissionais que fugiam da repressão do regime Duvalier e cuja formação lhes permitiu integrar-se na vida econômica da região. Essa "fuga de cérebros" representou uma perda irreparável para o Haiti (VILLEFRANCHE, 2014, p. S/N).

A partir de 1978, o entendimento Couture Cullen, assinado entre o Canadá e a província do Quebec, permitiu a essa ter autonomia nos critérios de seleção de estrangeiros. Houve, desde então, uma gestão descentralizada em províncias, comandada pelo governo federal. O Canadá priorizou a diversidade dos múltiplos grupos migratórios, dando-os o direito de expressarem suas singularidades culturais-religiosas, construindo aos poucos uma sociedade multicultural.

A migração haitiana continuou crescendo nas décadas seguintes caracterizandose, sobretudo por uma "fuga de braços". Entre 1976 e 2003, cerca de 59.300 haitianos instalaram-se no país. O menor grau de instrução fez com que muitos tivessem dificuldade de se recolocar e manifestaram-se problemas ligados à marginalização desse segmento da população como: desemprego, evasão escolar, família monoparental, criminalidade, etc. Significativo ponderar que, se de um lado há um grupo de haitianos com pouca 
escolaridade, ocupando o setor de trabalho desvalorizado no país, de outro lado, há um grupo de profissionais muito bem qualificado que fugiram da ditadura de Duvalier, como professores, engenheiros, médicos, advogados, etc.

Alguns haitianos ganharam expressivo destaque na sociedade canadense e internacional, por exemplo, Michaëlle Jean, que saiu do Haiti em 1968, foi a terceira mulher e a primeira pessoa negra a ser Governadora-Geral do Canadá em 2005; Dany Laferrière, refugiado para o país em 1976, é um consagrado jornalista, escritor, e roteirista, ganhador do prêmio Médicis em 2009 e aceito como membro da Academia Francesa em 2013 (VILLEFRANCHE, 2014, p.S/N; AUDEBERT, 2012, p. 80). A presença haitiana no Canadá, particularmente na província de Quebec, deu origem a uma cultura híbrida e verdadeiramente transnacional. A literatura é um dos terrenos onde se pode apreciar a originalidade dessa contribuição (KWATERKO, 2002; PETERSON, 2016).

Em 2002, o governo federal estabeleceu o Immigration and Refugee Protection Act. Este estabeleceu diretrizes delineadoras, como as definições de imigrante, as condições para a sua autorização legal e a permanência em território canadense, além de embasar as políticas públicas e a política imigratória do país. Ele não é um ato propositivo-normativo centralizador, como é, por exemplo, o Estatuto do Estrangeiro no Brasil ou as normas do CNIg, as províncias possuem certa autonomias. Há, segundo Atkinson et al (2013, p.44), um intergovernamentalismo, ou seja, existem relações verticais entre o governo central e as províncias e os territórios, porém há, também, as relações horizontais entre as unidades constituintes.

Isso proporciona que a estruturação das políticas públicas seja orientada pelo governo central. Contudo, diferentemente do modelo federalista brasileiro, as províncias possuem mais liberdade para construir políticas, isoladas ou conjuntamente, em cima das diretrizes sem a participação direita da união. Esse modelo permite que o governo federal se mantenha forte e com legitimidade constitucional, mas ao mesmo tempo descentralizado. A província francófona do Quebec, que possui um forte movimento separatista, inclusive pleiteando sua independência em 1995 por meio de um plebiscito, é uma das que mais elaboram políticas públicas sem a ingerência direta de Ottawa. Os setores de saúde, de comércio e de imigração são as áreas que têm mais atuação e autonomia provincial. 
Em relação à imigração, o governo federal estabelece, por meio do Immigration, Refugees and Citizenship Department, critérios de seleção de imigrantes e de refugiados, bem como a categorização deles, porém o fluxo obedece dois critérios: o fluxo federal e o Provincial Nominee Programs (PNP). Desse modo, Quebec, por exemplo, possui sua legislação e sua própria política sobre o tema, concentrado no departamento de Immigration, Diversité et Inclusion Québec. Outras províncias também possuem seus próprios programas, como Alberta Immigrant Nominee Program com diferentes categorias para pleitear a imigração (BAGLAY, 2012, p.130-131; CAMERON, SIMEON, 2002, p.49-50).

A maior autonomia das unidades federativas permite mais flexibilidade para formulação de políticas públicas para incentivo de imigrantes econômicos, viabilizando que cada província estabeleça suas demandas demográficas e laborais, caso que não ocorre no Brasil em virtude do engessamento legislativo. Além disso, possibilita o encaminhamento de refugiados e de imigrantes para abrigos e integração social mais rápida.

O governo central, a partir dos anos 2000, reorientou ainda mais suas diretrizes regulatórias. Desde então, critérios como: vínculos familiares, razões humanitárias e as qualificações profissionais passaram a ter maior peso para admissão no país. Nesse ensejo, em 2004, quando ocorreram as violentas insurreições populares que levaram a Minustah ao Haiti, o governo canadense decretou uma moratória impedindo que os haitianos fossem expulsos do país por estarem sem documentação legal por causa de solicitação de asilo ou refúgio indeferida. A moratória foi sendo renovada de maneira contínua até 2014, quando o governo conservador de Stephen Harper julgou que a situação no Haiti e no Zimbábue (país também incluído) estava suficientemente estabilizada.

Quando do terremoto de 2010, as autoridades de Quebec rapidamente lançaram um programa de acolhida humanitária com foco na reunião de parentes. Em um período de dois anos, segundo dados do Ministère de l'immigration, de ladiversité et de l'inclusion $d u$ Quebec, a província recebeu 8.400 haitianos de todas as categorias de imigração. O atual governo liberal do Primeiro Ministro Justin Trudeau, filho de Joseph Trudeau, vem fazendo uma política, assim como o pai, pautada na importância do multiculturalismo 
e na diversidade, ampliando o prazo para apresentação dos documentos de residência permanente por considerações humanitárias para agosto de 2016.

Segundo dados do Statistique Canada vivem atualmente no Canadá, entre recémchegados e cidadãos de segunda e terceira geração, cerca de 130.000 haitianos, os de primeira geração são aproximadamente 93 mil. É o $10^{\circ}$ grupo demográfico entre não europeus. Os haitianos, no Canadá, tem menor grau de escolaridade e costumam ocupar empregos técnicos no setor da manufatura. A taxa de desemprego é mais elevada entre eles $(16,4 \%)$ do que no restante da população $(7,4 \%)$ e sua renda costuma ser $30 \%$ inferior. Há três vezes mais mães solteiras. As famílias haitianas têm uma maior tendência a serem monoparentais com a mulher ocupando a posição de chefe de família.

Embora a sociedade civil organizada, como ONGs e instituições filantrópicas e religiosas desempenhe papel importante para integração dos imigrantes haitianos e outros no Canadá, o papel delas não é sobrecarregado tal como é no Brasil. As províncias conseguem atender a demanda, organizando e regulamentando o fluxo. As principais organizações da sociedade civil, como Family Services, Immigrant Services Society, St Christopher House, South Okanagan Immigrant and Community Services, etc. desempenham, portanto, um papel coadjuvante e não de protagonista na integração do imigrante como acontece no Brasil.

O amparo provincial dado ao imigrante faz com que o Canadá seja eleito pelo MIPEX como o sexto país com as melhores políticas de integração do imigrante. O MIPEX elabora diversas categorias de análises, por exemplo, em política de antidiscriminação, o Canadá é o primeiro, isto é, a defesa do multiculturalismo canadense é referência internacional. Isso não significa que os canadenses não tenham reações de xenofobia, mas revela a determinação do Estado de agir contra a discriminação com políticas claras e eficazes. Em outras categorias como: incentivo à reunião familiar e acesso à educação o país é o quarto colocado. Infelizmente o Brasil não é avaliado pelo MIPEX e tampouco possui seu próprio índice de medição das qualidades de política de integração do imigrante. 


\section{Considerações finais}

O objetivo do estudo comparativo das políticas de integração do imigrante do Brasil e do Canadá tendo como estudo de caso a imigração haitiana procurou demonstrar como se organiza cada país nessa temática. No tocante à regulamentação ficou visível que ambos os países, apesar de serem federativos, adotam modelos diferentes. O Brasil concentra toda legislação regulatória e seus pormenores na União, enquanto o Canadá permite que as províncias tenham certa autonomia, o governo federal fica encarregado de nortear e de conceitualizar as políticas.

O modelo canadense, por um lado, permite que as províncias se interessam mais pelo tema e vejam sua importância para construção de uma nação multicultural, organizando seus próprios ministérios, demandas e interesses; por outro lado, faz com que, com maior poder, elas possam criar barreiras de entradas não previstas nas leis federais. O governo de Quebec, por exemplo, vem adotando uma visão mais intercultural e transcultural do que multicultural.

O modelo, todavia, permite maior participação política dos cidadãos de cada província em virtude da proximidade e da vivência dos debates, inclusive os próprios imigrantes e suas redes pré-estabelecidas na região. No caso dos haitianos o Conselho Canadense de Cidadãos de Origem Haitiana realiza trabalho constante junto com o governo de Quebec, funcionando como importante ator político na luta pelos direitos aos imigrantes.

No modelo brasileiro, apesar dos avanços na nova Lei da Migração de 2017, a política continua centralizadora fazendo com que os estados federativos percam poder de preceituar pormenorizadamente sobre o tema. A centralização inviabiliza, por exemplo, que cada estado tenha suas próprias políticas de regulação migratória. Se por um lado isso evita a seleção não humanitária por parte das unidades federativas, por outro lado não possibilita com que uma demanda regional seja mais prontamente atendida. Por exemplo, um estado federativo não poderia criar uma lei facilitando o visto para parentes de outros imigrantes que já estão alocados em seu território; ou a adoção de visto laboral.

No caso dos haitianos, a maioria, segundo Moraes, Andrade e Mattos (2013, p.100), entrou pelo país via Acre, mas não permaneceu por lá. Muitos foram para a região 
sul do país em virtude de maior demanda por mão de obra. Se existisse uma política descentralizada, os entes federativos que necessitassem de mão de obra poderiam realizar uma campanha com facilidades para a informação e atração de imigrantes. Tal modelo, além de permitir maior participação da população local na formulação de políticas públicas, criaria uma cultura democrática no país e serviria de norteador importante para o próprio imigrante na busca de sua estabilização no novo território.

No que diz respeito às políticas de integração do imigrante, os dois países diferem drasticamente. Enquanto no Canadá o Estado está altamente preocupando em integrar o recém-chegado na sociedade, dando suporte público para sua inserção social, laboral e cultural, no Brasil não existe uma política clara em defesa da integração das comunidades culturais distintas. A integração fica por conta da sociedade civil organizada e, em raros casos, algumas prefeituras ou estados federativos adotam medidas pontuais.

O papel da sociedade civil organizada é extremamente importante, porém carece de uma regulamentação mais delineadora e nem sempre possui capacitação para realizar o delicado processo de integração do imigrante. Muitas trabalham alicerçadas no serviço voluntário e apesar da importância da boa vontade dos voluntariados a da falta de profissionais qualificados para atender especificamente esse público, como a presença de assistentes sociais, de psicólogos, de pedagogos, etc. torna o trabalho, às vezes, pouco eficiente. Por exemplo, um profissional treinado seria capaz de perceber se determinado imigrante está sendo coagido, se uma criança está sofrendo abusos, se o recém-chegado está passando por algum processo de desequilíbrio emocional, etc.

Salienta-se, ademais, que o trabalho da sociedade civil organizada no Brasil, embora louvável, não sofre medição de qualidade tal como as políticas públicas canadenses e de outros 37 países que são avaliados pelo MIPEX. Não que esse indicador seja infalível ou não apresente discrepâncias com a realidade, porém é um importante índice para compreender e para avaliar as políticas de integração do imigrante em um país. O governo brasileiro poderia, portanto, estabelecer regras mais claras para as entidades não governamentais que atuam nessa seara, além de dar maior suporte a elas, realizando, desse modo, uma cooperação estratégica de política social, aproveitando, assim, as redes já estabelecidas por essas entidades. Além disso, seria interessante, fomentar junto 
às universidades latino-americanas, com seus grupos de pesquisas sobre a temática, a criação de um índice sobre as políticas de integração ao imigrante na região.

Destaca-se que tanto o Canadá quanto o Brasil perceberam a complexidade do caso haitiano, por extrapolar as tradicionais definições de migrante e de refugiado. Em entrevistas com haitianos presentes na cidade de São Paulo, evidenciou-se que muitos não saem de seu país somente em busca de oportunidades econômicas, eles são motivados, sobretudo, em virtude da crise humanitária provocada por uma sucessão de desastres políticos e naturais e que deteriora ainda mais as frágeis circunstâncias sociais nacionais. Desse modo, ambos os países diferentemente de outras nações da região, optaram em adotar um visto especial, o visto humanitário para os haitianos.

Neste momento, as nações das Américas, inclusive o Brasil, vêm passando por um renascimento de grupos políticos com viés fascista-nacionalista explicito. Esses vêm desencadeado surtos de ódios a determinados grupos, entre eles, os imigrantes. Uma busca rápida por notícias de crimes de ódio contra os haitianos encontrará vários casos, como o do haitiano Fetiere Sterlin, espancado até a morte em Navegantes (SC); ou de Jean Lorchend Ismael Eugene, haitiano em situação de rua, baleado em Pinhais (PR). Ambos os casos foram relacionados a discurso de ódio (SPERB, 2015, p. S/N; JUBANSKI, NASCIMENTO, 2017, p. S/N).

Há muita desinformação sobre o tema da imigração, fazendo com que setores da mídia, grupos políticos e comunidade em geral vejam a questão como algo negativo e prejudicial ao país. A população local, ao identificar no imigrante uma ameaça a sua simbologia, suas tradições e ao seu poder político-econômico pode enveredar para o xenofobismo, o etnicismo e o racismo.

O relativo sucesso da política de diversidade cultural canadense implantada desde a década de 60 conseguiu institucionalizar a defesa do multiculturalismo e da não discriminação, algo crucial em um período que muitos países fazem um retrocesso nessa área. Como apresentado pelo texto, a defesa, por parte do Estado, pela não discriminação quer dizer necessariamente que não haja xenofobia, mas deixa claro que o Estado não compactua com essa prática e adota políticas para combatê-la e salvaguardar o imigrante. 
É preciso divulgar informações sobre os impactos sociopolíticos que a imigração internacional gera no país a curto, médio e longo prazo para que diminuam as tensões de sociabilidade, étnicas, linguísticas e política-socioeconômica Poucos percebem que a imigração é uma ferramenta fundamental para promover o consumo, a diversidade cultural, a criação de investimentos e melhorar os níveis de produtividade e inovação tecnológica do país. Ações dessa natureza promoveriam maior interação da comunidade já estabelecida no país com os recém-chegados, incentivando, assim, a multiculturalidade e a integração.

\section{Referências}

ACNUR - Agência da Onu para refugiados. Global trends: forced displacement in 2015. Disponível em: <http://www.unhcr.org/statistics/unhcrstats/ 576408cd7/unhcr-globaltrends-2015.html > Acesso em 12 de fev. 2017.

ACNUR. PROTECTION INDICATORS. Disponível em: <http://www.unhcr. org/40eaa9804.pdf $>$ Acesso em 23 de abri. 2016.

ATKINSON, Michael M. et al. Governance and Public Policy in Canada: A View from the Provinces. Toronto: University of Toronto Press, 2013.

AUDEBERT, Cédric. La diaspora haïtienne: Territoires migratoires et réseaux transnationaux. Rennes: Presses Universitaires de Rennes, 2012.

BAGLAY, Sasha. Provincial Nominee Programs: A Noteon Policy Implications and Future Research Needs. International Migration \& Integration, [s.1.], v. 13, n. 1, p.121-141, fev. 2012. Disponível em: <http://link.springer.com/article/10.1007/s12134011-0190-8> Acesso em: 20 fev. 2017.

CAMERON, David \& SIMEON, Richard. Intergovernmental Relations in Canada: The Emergence of Collaborative Federalism. Publius: The Journal of Federalism, Easton, v. 32, n. 2, p.49-72, 2002. Disponível em: <http://publius.oxfordjournals.org/content/32/2/49.abstract> Acesso em: 20 fev. 2017.

CAVALCANTI, Leonardo; OLIVEIRA, Antônio T. \& ARAUJO, Dina. Relatório Anual 2016: A inserção dos imigrantes no mercado de trabalho brasileiro. Brasília: Observatório das Migrações Internacionais (OBMigra), 2016. Disponível em: <http://obmigra.mte. gov.br/index.php/relatorio-anual> Acesso em 14 de jan. 2017.

CCR - Conseil canadien pour les refugiés. 100 ans d'immigration au Canada 19001999. 2000. Disponível em $:<$ http://ccrweb.ca/fr/100-ans-immigration-canada $>$ Acesso em 29 de jan. 2017.

CONECTAS. Crise Invisivel: O Caso dos Migrantes Haitianos no Brasil. São Paulo: Conectas, agosto de 2013. Disponível em: <http://relatorio-conectas.org/2013/wp-con- 
tent/uploads/2014/09/relatorio-conectas-politica-externa-ago2013.pdf $>$ Acesso em 15 de dez. 2017.

FERNANDES, Duval \& CASTRO, Maria da Consolação G. de. (org). Estudo sobre a Imigração Haitiana ao Brasil e Diálogo Bilateral. Belo Horizonte: MTE/PUC-MG/OIM, 2014.

GREEN, Alan G.\& GREEN, David A. The Economic Goals of Canada's Immigration Policy. Discussion Paper, Vancouver, v. 18, n. 96, p.1-49, jul. 1996. Disponível em: $<$ http:// citeseerx.ist.psu.edu/viewdoc/download?doi=10.1.1.195.7776\& rep=rep1\&type=pdf $>$ Acesso em: 14 de fev. 2017.

HELLY, Denise. Primacía de los derechos o cohesión social: os límites del multiculturalismo canadiense. Acciones e Investigaciones Sociales, [s. L.], n. 15, p.5-28, out. 2002. Disponível em: <http://dialnet.unirioja.es/servlet/articulo?codigo=284112> Acesso em: 15 de fev. 2017.

JUBANSKI, Elizangela \& NASCIMENTO, Antônio. Jovem haitiano é morto por rapazes de bicicleta em Pinhais. Curitiba: Banda B, 2017. Disponível em: <http://www.bandab. com.br/seguranca/jovem-haitiano-e-morto-por-rapazes-de-bicicleta-em-pinhais/> Acesso em 10 de jan. 2018.

KWATERKO, Józef. Ficções Indenitárias no Quebec: o ponto de vista da crítica. Interfaces Brasil/ Canadá. Porto Alegre, v.1, n. 2, 2002, p. 107-118. Disponível em:<https:// periodicos.ufpel.edu.br/ojs2/index.php/interfaces/article/view/6375> Acesso em 12 de janeiro 2018.

LAITIN, David. Comparative Politics: the State of the Subdiscipline. In. Ira Katznelson \& Helen Milner, Political Science. State of Discipline. Norton: New York, 2002, p. 630-651.

LESSER, J. Legislação imigratória e dissimulação racista no Brasil (1920-1934). Arché. Rio de Janeiro: v. 3, n. 8, 79-98, 1994.

MINISTÈRE DE L'IMMIGRATION, DE LA DIVERSITÉ ET DE L'INCLUSION DU QUEBEC. Deux ans aprés le séisme en Haiti. 2012. Disponível em: <http://www.midi. gouv.qc.ca/fr/presse/communiques/com20120111.html> Acesso em 07 de jan. 2017.

MIGRATION POLICY INSTITUTE. Immigrant and emigrant populations coutry origin and destination. Diponível em: <http://www.migrationpolicy. org/programs/data-hub/ charts/immigrant-and-emigrant-populations-country-origin-and-destination $>$ Acesso em 15 de fev. 2017.

MIPEX. Migrant Integration Policy Index. Disponível em: <http://www.mipex.eu/> Acesso em 23 de abri. 2016.

MEYERS, E. International Immigration Policy: A theoretical and Comparative Analysis. New York: Palgrave Macmillan, 2004.

MORAES, Isaías A.; ANDRADE, Carlos \& MATTOS, Beatriz. A Imigração Haitiana para o Brasil: Causas e Desafios. Porto Alegre: Revista Conjuntura Austral, Vol. 4, nº 20, Out. Nov. 2013, p. 95-114. Disponível em: <http://seer.ufrgs.br/ConjunturaAustral/ 
article/view/35798> Acesso 18 de fev. 2017.

MCH - MUSEE CANADIEN DE L'HISTOIRE. Um aperçu historique de l'immigration au Canada. Disponível em : < http:/www.museedelhistoire.ca/cmc/exhibitions/tresors/ immigration/imf0304f.shtml > Acesso em 08 de fev. 2017.

OBMigra. Observatório das Migrações Internacionais. Disponível em <http://obmigra. mte.gov.br/> Acesso em 10 de nov. 2016.

OLIVEIRA, Antônio Tadeu Ribeiro de. Nova lei brasileira de migração: avanços, desafios e ameaças. Rev. bras. estud.popul., São Paulo, v. 34, n. 1,p. 171-179. Diponível em: <http:// www.scielo.br/scielo.php?script=sci_arttext\&pid=S0102-30982017000100171\&lng=en $\& n r m=$ iso $>$ Acesso em 10 de jan. 2018 .

PAIVA, Odair da Cruz. Refugiados da Segunda Guerra Mundial e os Direitos Humanos. DIVERSITAS - Núcleo de Estudos das Diversidades, Intolerâncias e Conflitos, 2009. Disponível. Disponível em: < http://diversitas.fflch.usp.br/node/2180> Acesso em 03 de fev.. 20017.

PETERSON, Michel. Recomposition des imaginaires dans les littératures et les diasporas caribéenes. Interfaces Brasil/Canadá. Florianópolis/Pelotas/São Paulo, v. 16, n. 3, 2016, p. 168-181. Disponível em: <https://periodicos.ufpel.edu.br/ojs2/index.php/interfaces/article/view/10105> Acesso em 12 de janeiro 2018.

RAGIN, Charles. The Comparative Method: Moving Beyond Qualitative and Quantitative Strategies. Berkeley: University of California Press, 2014.

SCHMITTER, Philippe. Comparative Politics in Krieger, Joel (org.) The Oxford Companion to the Politics of the World. Nova York, Oxford University Press, 2001.

SISTEMA NACIONAL DE CADASTRAMENTO DE REGISTRO DE ESTRANGEIROS (SINCRE) DA POLICIA FEDERAL. 2017. Registro de Estrangeiros. Disponível em: <http://www.pf.gov.br/imprensa/estatistica/estrangeiros>Acesso em 23 de nov. 2017.

SPERB, Paula. Haitiano é agredido até a morte em Santa Catarina. Porto Alegre: Folha de São Paulo, 2015. Disponível em: <http://www1.folha.uol.com.br/ cotidiano/2015/10/1696121-haitiano-e-agredido-ate-a-morte-em-santa-catarina.shtml $>$ Acesso em 10 de jan. 2018.

STATCAN. Statistique Canada. La communauté haitienne au Canada. 2001. Disponível em: <http://www.statcan.gc.ca/pub/89-621-x/89-621-x2007011-fra.htm> Acesso em 29 de jan. 2017.

TORPEY, John. Statesand the Regulation of Migration. In. ANDREAS, Peter; SNYDER, Timothy (Org.) The Wall around the West: State Borders and Immigration Controls in North America and Europe. New York: Rowman \& Little Field Publs., Inc., 31-54, 2000.

VILLEFRANCHE, Marjorie. Partir pour rester: l'immigration haitienne au Quebec. 2014. Disponível em <http://www.mhaiti.org/media/communaute-haitienne> Acesso em 22 de jan. 2017. 
VINDA DE HAITIANOS É MAIOR INDA IMIGRATÓRIA AO PAÍS EM CEM ANOS. São Paulo: Jornal Folha de S. Paulo 12/01/2012. Disponível em: <http://www1.folha. uol.com.br/mundo/1033447-vinda-de-haitianos-e-maior-onda-imigratoria-ao-pais-emcem-anos.shtml $>$ Acesso em 12 de jan, 2017.

ZOLBERG, A. R. A Nationby Design - Immigration Policy in the Fashioning of America. New York: Russell Sage Foundation, 2006.

\section{Notas}

${ }^{1}$ Artigo realizado conjuntamente, cabendo metade da pesquisa e da redação a cada um. Atenção especial de Isaías Albertin de Moraes para primeira seção e Mônica Heinzelmann Portella de Aguiar para segunda.

${ }^{2}$ Doutorando em Ciências Sociais pela Universidade Estadual Paulista "Júlio de Mesquita Filho" (UNESP), Araraquara, SP, Brasil. Bolsista da Coordenação de Aperfeiçoamento de Pessoal de Nível Superior (CAPES). isaiasalm@gmail.com.

3 Professora Adjunta do Departamento de Ciência Política da Universidade Candido Mendes (UCAM), RJ, RJ, Brasil. Doutora em Ciência Política pelo Instituto Universitário de Pesquisas do Rio de Janeiro (IUPERJ/UCAM).

${ }^{4}$ Segundo o Migration Policy Institute as nações que mais receberam imigrantes haitianos são: EUA (604 mil), a República Dominicana (329 mil), Canadá (93 mil), a França (74 mil), as Antilhas Francesas (50 mil), e, mais recentemente o Brasil (60 mil) (Migration Policy Institute, 2015).

${ }^{5}$ O MIPEX é uma ferramenta, elaborada pelo Centro de Barcelona para Assuntos Internacionais - CIDOB e o Migration Policy Group - MPG e reconhecida como referência internacional. Ela mede as políticas de integração dos imigrantes na União Europeia, Austrália, Canadá, Islândia, Japão, Coréia do Sul, Nova Zelândia, Noruega, Suíça, Turquia e EUA.

6 Não há registro de que o decreto tenha sido diretamente invocado para proibir a entrada de negros, mas sinaliza a intenção das autoridades a esse respeito. Ver mais em http://www.quai21.ca/recherche/histoire-dimmigration/decret-du-conseil-cp-1911-1324. 